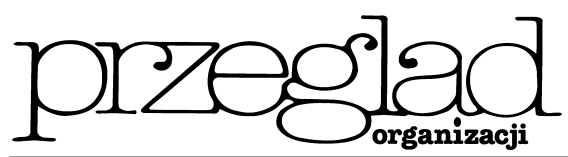

\title{
Six Sigma a kultura organizacyjna
}

https://doi.org/10.33141/po.2005.78.01

Robert Kamiński

\section{Wstęp}

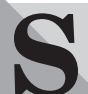

ix Sigma to program zapoczątkowany przez Motorolę. W latach 70. ub. wieku na rynku amerykańskim nastąpił kryzys, a produkty japońskie zaczęły zdobywać rynek. W przedsiębiorstwach amerykańskich zaczęto zastanawiać się, co należy zrobić, aby nie przegrać z dalekowschodnią konkurencją. Poszukiwano metody, która poprawi jakość produktów i usług oraz pozwoli zwiększyć oszczędności dzięki podwyższonej jakości. Tak więc kierownictwo Motoroli zatrudniło wyspecjalizowaną kadrę, która stworzyła system ciągłej poprawy jakości - Six Sigma.

Six Sigma zdefiniować można jako zestaw reguł postępowania skoncentrowanych na jakości procesów i ograniczeniu w nich zmienności (liczby błędów), co wpłynąć ma na zwiększenie rentowności przedsiębiorstwa. Six Sigma łączy jakość z wynikami finansowymi przedsiębiorstwa i zaprzecza lansowanej przez wiele lat strategii TQM, że jeśli poprawi się jakość, wyniki finansowe przyjdą same [5].

W literaturze przedmiotu podaje się czynniki sukcesu we wdrażaniu programu jakości Six Sigma. Z. Zymonik [5] zauważa, że czynniki te mogą okazać się również barierą we wdrażaniu programu Six Sigma, jeśli kultura organizacji nie jest odpowiednia. W niniejszym opracowaniu podjęto próbę określenia rodzaju kultury organizacyjnej będącej podstawą dla jego wprowadzenia i funkcjonowania. Wykazano, że kulturą tą będzie otwarta kultura organizacyjna. Ma ona znaczenie w realizacji takich elementów programu Six Sigma, jak: orientacja na proces, pomiary, demaskowanie błędów i koncentracja na usuwaniu długotrwałych problemów.

\section{Otwarta i zamknięta kultura organizacyjna}

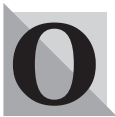

twarta i zamknięta kultura organizacyjna oparta została na teorii społeczeństwa otwartego i zamkniętego K. Poppera. Te dwa typy społeczeństwa można opisać za pomocą trzech wymiarów: antropologicznego, socjalnego i poznawczego [1].

Wymiar antropologiczny określa stosunek człowieka do otaczającego go świata. Człowiek może być albo pasywnym przedmiotem, który podlega deterministycznej sile otaczającego go świata (społeczeństwo zamknięte) albo aktywnym, zaopatrzonym w inicjaty-
Przegląd Organizacji, Nr 7/8 (786/787), 2005, ss. 7-10 www.przegladorganizacji.pl Towarzystwo Naukowe Organizacji i Kierownictwa (TNOiK) wę i umiejętności stawiania czoła otoczeniu podmiotem (społeczeństwo otwarte). Społeczeństwo zamknięte jest zorientowane pod względem wymiaru socjalnego na tworzenie kolektywu, którego dobru można poświęcić dobro jednostki zgodnie z zasadą: kolektyw jest wszystkim, jednostka niczym. Społeczeństwo otwarte cechuje orientacja na jednostkę. W centrum uwagi stoi indywiduum, którego dobro jest celem wszystkich działań, a nie środkiem do celu, jak w społeczeństwie zamkniętym. W wymiarze poznawczym chodzi o odpowiedź na pytanie, czy ludzkie poznanie jest oceniane jako omylne (społeczeństwo otwarte), czy raczej jako pozbawione błędów i niezawodne (społeczeństwo zamknięte) [1]. Teoria społeczeństwa otwartego i zamkniętego została przeniesiona na poziom organizacji i odzwierciedlona w jej kulturze (tab. 1).

\section{Części składowe Six Sigma a otwarta i zamknięta kultura organizacyjna}

\section{Orientacja na proces}

Program Six Sigma koncentruje się na procesach. Proces jest definiowany jako zbiór uporządkowanych działań, w trakcie których wartość początkowa (nakład) jest wzbogacana o wartość dodatkową (wartość dodaną), w wyniku czego otrzymuje się wartość końcową przeznaczoną dla klienta (zwaną wartością konsumencka) [4]. Wartość ta może być zubożona przez

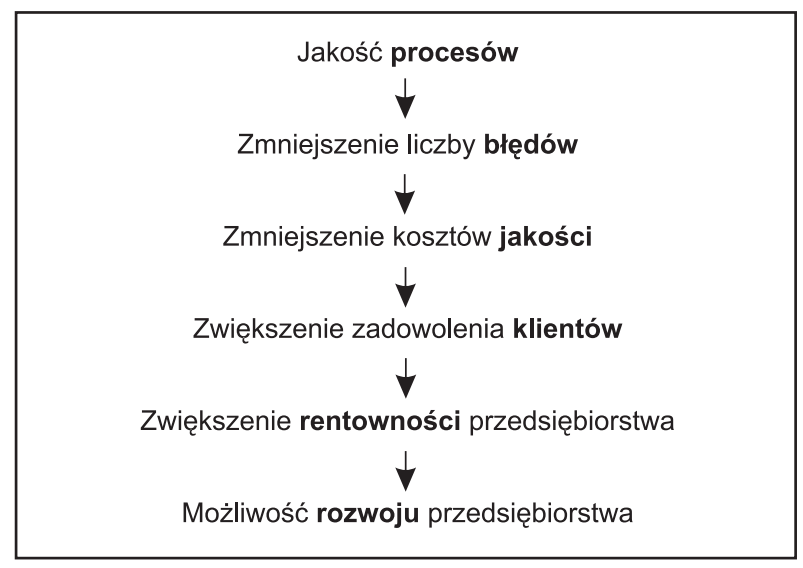

Rys. 1. Znaczenie orientacji na proces $w$ programie Six Sigma

Źródło: [5, s. 370]. 
Tab. 1. Otwarta i zamknięta kultura organizacyjna

\begin{tabular}{|c|c|}
\hline Otwarta kultura organizacyjna & Zamknięta kultura organizacyjna \\
\hline \multicolumn{2}{|c|}{ Wymiar antropologiczny } \\
\hline $\begin{array}{l}\text { Organizacja sama kształtuje swoją rzeczywistość według } \\
\text { własnej woli }\end{array}$ & Organizacja podlega wpływowi z zewnątrz \\
\hline $\begin{array}{l}\text { - Istnieją alternatywne sposoby działania } \\
\text { - Reguły organizacyjne są wynikiem kompromisu } \\
\text { - Aktywność i działanie - w przypadku napotkania } \\
\text { trudności przeciwdziała się }\end{array}$ & $\begin{array}{l}\text { - Brak alternatywnych sposobów działania } \\
\text { - Reguły organizacyjne odzwierciedlają nakazy, rozporzą- } \\
\text { dzenia, instrukcje } \\
\text { - Pasywność i brak działania (np. w przypadku trudności } \\
\text { czeka się) }\end{array}$ \\
\hline \multicolumn{2}{|c|}{ Wymiar socjalny } \\
\hline Partykularyzm - ochronie podlega jednostka & Holizm - ochronie podlega kolektyw \\
\hline $\begin{array}{l}\text { - Jednostka może samodzielnie określać swoją pozycję } \\
\text { - Ludzie są równi i zdolni do rozwoju } \\
\text { - Ludzie mają potrzebę samorealizacji }\end{array}$ & $\begin{array}{l}\text { - Jednostce przypisuje się jej pozycję } \\
\text { - Ludzie są nierówni i niezdolni do rozwoju } \\
\text { - Ludzie wypełniają misję wspólnoty }\end{array}$ \\
\hline \multicolumn{2}{|c|}{ Wymiar poznawczy } \\
\hline $\begin{array}{l}\text { Poznanie i odkrywanie wiedzy jako proces ciągłych } \\
\text { ulepszeń }\end{array}$ & Bezkrytyczne wprowadzanie w życie ostatecznych ideałów \\
\hline $\begin{array}{l}\text { - Prawda jako wynik racjonalnego procesu } \\
\text { - Idea ciągłych ulepszeń (poszukiwanie optimów lokal- } \\
\text { nych) mających na celu redukcję kompleksowości } \\
\text { - Niepewność i generowanie nowych pomysłów wymaga } \\
\text { udziału wszystkich }\end{array}$ & $\begin{array}{l}\text { - Prawda jako objawiony dogmat } \\
\text { - Realizacja rozwiązań najlepszych (poszukiwanie opti- } \\
\text { mum absolutnego, ideału), które redukują kompleksowość } \\
\text { - Pewność i realizacja idei legitymuje monopol władzy } \\
\text { „mędrców” }\end{array}$ \\
\hline
\end{tabular}

Źródło: opracowanie własne na podstawie [1].

różnego rodzaju zakłócenia w procesie. Czynniki zakłócające należą głównie do pięciu obszarów: człowiek, maszyny i urządzenia, metody, materiały i zarządzanie. W przedsiębiorstwach, we wszystkich sferach ich działalności, zachodzą codziennie tysiące procesów prowadzących do wytworzenia produktu finalnego i decydujących o rozwoju przedsiębiorstwa. Znaczenie orientacji na proces w programie Six Sigma przedstawiono na rys. 1.

W tym kontekście zapytać można, jakiej kultury organizacyjnej wymaga orientacja na proces. Jak zauważają G.A. Rummler i A.P. Brache [3] orientacja na proces zmusza do systemowego spojrzenia na organizację. Podejście systemowe ukazuje, w jaki sposób wykonywana jest praca i jak powiązane są elementy wewnątrz organizacji oraz sama organizacja z jej klientami i dostawcami - podstawą są więc procesy, które przekraczają granice między działami (funkcjonalnymi). Podejście systemowe jest zaprzeczeniem wertykalnego podejścia do organizacji, w którym cele działów funkcjonalnych są ustalane niezależnie od siebie, a ich przedstawiciele traktują pracowników innych działów jako wrogów. Horyzontalne lub inaczej systemowe podejście do organizacji ma więc zupełnie inną perspektywę i wiąże się z inną, systemową kultura organizacyjną (tab. 2).

Nakreślona powyżej systemowa kultura organizacyjna jest więc punktem wyjścia analizy i usprawniania procesów, gdyż umożliwia dostrzeżenie działań kreujących produkty i usługi. Okazuje się, że odpowiada ona otwartej kulturze organizacyjnej. Zrozumienie potrzeb klientów i wymogów wynikających z re-

Tab. 2. Porównanie tradycyjnej (wertykalnej) i systemowej (horyzontalnej) kultury organizacyjnej

\begin{tabular}{|c|c|}
\hline & \\
\hline $\begin{array}{l}\text { - Interesy działów dominują przy podejmowaniu decyzji } \\
\text { - Większość pracowników zna dobrze tylko zadania realizo- } \\
\text { wane w ich działach } \\
\text { - Pracownicy nie znają wewnętrznych klientów i dostaw- } \\
\text { ców oraz powiązań między nimi } \\
\text { - Konkurencja między działami } \\
\text { - Tylko wyniki pracy funkcji (działów) są mierzone i zarzą- } \\
\text { dzane }\end{array}$ & $\begin{array}{l}\text { podejmowaniu decyzji } \\
\text { - Pracownicy rozumieją, jak działa cała firma i działy, z któ- } \\
\text { rymi współpracują } \\
\text { - Pracownicy znają zasilenia oraz wyniki pracy łączące ich } \\
\text { dział z pozostałymi } \\
\text { - Poszczególne działy są dla siebie równorzędnymi partne- } \\
\text { rami } \\
\text { - Wyniki oraz procesy są stale analizowane i zarządzane }\end{array}$ \\
\hline
\end{tabular}

Źródło: [3]. 
alizowanych procesów zmusza do uwzględnienia innych, niż tylko własnych interesów. Istnieją alternatywne sposoby postępowania, które wymagają prowadzących do kompromisu uzgodnień, a stała analiza osiagganych wyników pociąga za sobą konieczność ciągłych ulepszeń.

\section{Pomiary}

Drugą częścią składową programu Six Sigma są pomiary. Biorac pod uwage zarówno badania, jak i wnioski z nich płynące, zwiększa się szanse, że firma będzie lepiej zaspokajała potrzeby swoich klientów. Mierząc jakość i wydajność procesów, obniża się koszty i poprawia jakość produktów. Według M. Harry'ego i R. Schroedera [2] wskaźniki są potrzebne, aby m.in.:

- ustalić różnicę między tym, co postrzegamy, a rzeczywistością;

- zebrać dane, na podstawie których będzie można podejmować decyzje i stworzyć podstawy do solidnego wykonania tych decyzji;

- przezwyciężyć bariery myślowe i nastawić się na myślenie wykraczające poza schematy;

- lepiej zrozumieć procesy przedsiębiorstwa i określić, które ich elementy są najistotniejsze;

- sprawdzić, czy procesy przebiegają zgodnie z normami, w ustalonych granicach tolerancji.

Six Sigma cechuje się więc permanentnym dokonywaniem pomiarów, co ma swój wpływ na kulture organizacyjną. W porównaniu z tradycyjną organizacja zmiany kulturowe dotyczą przede wszystkim orientacji na wyniki. Eliminuje się sens prowadzenia wszelkich działań pozornych lub takich, które nie zwiększają wartości końcowej przeznaczonej dla klienta. Wyniki są również podstawą systemu wynagradzania. Rację bytu traca więc inne założenia systemu wynagrodzeń, takie jak: opłacanie ludzi na podstawie zajmowanych $\mathrm{w}$ hierarchii stanowisk, płacenie ludziom za samo stawianie się do pracy lub dawanie podwyżek tylko dlatego, że minął kolejny rok.

Samo dokonywanie pomiarów i zorientowanie na wyniki nie jest jednak wystarczające, ponieważ tylko dobrze dobrane wskaźniki prowadzą do ograniczenia kosztów i zwiększenia satysfakcji klientów. M. Harry i R. Schroeder [2] zauważają, że należy określić czynniki mające zasadniczy wpływ na zadowolenie klienta i nazywająje cechami krytycznymi dla jakości. Można więc zapytać, jaka kultura organizacyjna sprzyjać będzie tak rozumianej orientacji na klienta. Okazuje się, że jest to możliwe tylko wtedy, kiedy w organizacji występuje pewien pluralizm wartości oraz gotowość uczestników organizacji do wykroczenia poza dotychczasowe role organizacyjne - sprzyja temu otwarta kultura organizacyjna. Reagowanie na potrzeby klientów wymaga jednak nie tylko myślenia, sprzeciwu, krytyki i innowacji ze strony pracowników, ale i systemu zarządzania, który zapewnia niezbędne strategiczne informacje do oceny zaobserwowanych danych oraz pozytywnie reaguje lub nawet aktywnie stymuluje tego typu inicjatywy. Jak zauważają M. Harry i R. Schroeder, „Dążenie do jakości rzędu 6 sigma wymaga, aby procesy mierzone były inaczej niż dotychczas. Pomiary powinny dotyczyć tych zjawisk, które są uważane za najistotniejsze w danej firmie. Powstaje dylemat: co mierzymy, a co powinniśmy mierzyć? Kierownictwo firmy powinno zadawać pytania o wydajność procesów, sposób projektowania produktów i ogólny poziom jakości, a nie o wyniki produkcji i budżet. Sukces Six Sigma zależy od zadawania nowych pytań i zdobywania tą drogą nowych informacji, dzięki którym można doprowadzić do stworzenia nowych wskaźników" [2, s. 79].

\section{Demaskowanie błędów (ukrytych procesów)}

Ukryte procesy to procesy i systemy służące do naprawiania błędów, jakie powstały w trakcie produkcji dóbr lub świadczenia usług. Zajmują one niepotrzebnie przestrzeń produkcyjną, zużywają czas i inne zasoby przedsiębiorstwa. Sygnalizowane przez pracowników w okresowych sprawozdaniach koszty zużycia dodatkowych materiałów i robocizny są mierzone i zapisywane w sposób jawny. Przeciwnie, koszty ukrytych procesów są to koszty, o których kierownictwo się nie dowiaduje [2].

Demaskowanie ukrytych procesów możliwe jest dzięki stosowaniu wielu wskaźników. Należą do nich: wskaźnik wydajności przejściowej, wskaźnik wydajności mierzonej w toku i znormalizowany wskaźnik wydajności. Jednak motywacyjne działanie Six Sigma będzie zagwarantowane tylko wtedy, gdy uczestnicy organizacji rozumieć będą nie tylko stosowane mierniki, ale i związek ich pracy z tymi właśnie miernikami. Wymaga to od nich poczucia odpowiedzialności za wyniki, a co się z tym wiąże i wewnętrznego umiejscowienia kontroli. M. Harry i R. Schroeder [2] zauważają, że jakość musi dotyczyć pracowników osobiście (a nie całego procesu, który jest anonimowy i z którym mogą się oni nie utożsamiać), a sama sytuacja musi być dla nich przejrzysta (przyczyny wydarzeń i ich związek z przyjętym systemem wartości muszą być ewidentne).

Wewnętrzne umiejscowienie kontroli występuje jednak w organizacjach cechujących się otwartą kulturą organizacyjną [1]. Zakłada ona samodzielność, wolność i swobodę w podejmowaniu decyzji przez pracowników, a dominującymi wartościami są: inicjatywa, zaangażowanie, spontaniczność, dynamika, przygoda i gotowość ponoszenia ryzyka. W zamkniętej kulturze organizacyjnej, w której przeważa brak własnej inicjatywy, wysoki stopień centralizacji i przymus wynikający z hierarchii, pracownicy nie wierzą w to, że sami mogą wpływać na funkcjonowanie organizacji [1].

\section{Koncentracja na usuwaniu długotrwałych problemów}

Według M. Harry'ego i R. Schroedera [2] większość problemów występujących w procesach przedsiębiorstwa ma charakter długotrwały. Są one głęboko zako- 
rzenione, niełatwe do wykrycia i rozwiązania, a ich koszty traktowane są przeważnie jako straty, których nie da się uniknąć. W tradycyjnych przedsiębiorstwach większą uwage przywiązuje się więc do problemów sporadycznych. Niestety, rozwiązania problemów sporadycznych nie wpływają na zmniejszenie przeciętnej liczby wad i podniesienie jakości procesów. Główna przyczyną nadmiernych kosztów jakości są więc problemy długotrwałe, chroniczne i ukryte, które nie przyciągają tak uwagi, jak problemy sporadyczne. Problemów długotrwałych nie sposób usunąć, nie wiedząc, w jaki sposób należy mierzyć, analizować, doskonalić i kontrolować procesy. Po każdej awarii przychodzi fala pomysłów, wprowadzane są nowe zasady postępowania, co wręcz gwarantuje ponowne pojawienie się „starego" problemu (i prawdopodobnie jeszcze kilku nowych), ponieważ jego prawdziwe przyczyny nie zostały usunięte.

Program Six Sigma postuluje więc innowacyjne myślenie: „W organizacjach, w których wprowadzano Six Sigma, okazywało się, że po osiągnięciu około 5 sigma jedynym sposobem na dalsze doskonalenie jakości jest zupełne przeprojektowanie produktów i usług przez zastosowanie procesu o nazwie «projektowanie dla celów Six Sigma»" [2, s. 145]. Postępowanie to nawiązuje do teorii zmian pierwszego i drugiego rzędu. W przypadku zmian pierwszego rzędu dąży się do stabilizacji, ładu ustanowionego wokół punktu równowagi i panowania nad fluktuacjami. W przypadku zmian drugiego rzędu dominuje brak pewności, system stara się wprowadzić innowację, co oznacza gwałtowny zwrot zarówno w sposobach myślenia, jak i w działaniu, co w kontekście programu Six Sigma oznacza usunięcie problemów długotrwałych.

Takiemu innowacyjnemu myśleniu sprzyjają przede wszystkim [2]:

- Projektowanie rozwiązań i ulepszeń w wielofunkcyjnym zespole pracowników, którzy reprezentuja wszystkie dziedziny wiedzy i wszelkie umiejętności potrzebne w danym procesie. W zespołach wielofunkcyjnych łatwiejszy jest dostęp do informacji, którymi dysponują inni członkowie zespołu, dzięki czemu decyzje sa podejmowane na podstawie rzeczywistych danych, a nie, jak w zespołach tradycyjnych - na podstawie danych szacunkowych.

- Nieustanne zadawanie pytań, które dotyczyć mają wszystkiego, co organizacja chce usprawnić; powoduje ono, że zaczynają zachodzić zmiany w organizacji, ponieważ zrywa się ze spokojem, jaki był dotychczas.

- Obowiązująca wizja lub misja organizacji - długoterminowa perspektywa realizacji celów powoduje, że pracownicy nie zajmują się naprawianiem drobnych wad, ale wytrwale dążą do doskonalenia procesów. Sukces firmy budowany jest na wizji i wartościach, jakimi kierują się jej przywódcy. Motorem Six Sigma jest pragnienie zrealizowania wizji przyszłości przedsiębiorstwa. Wizja ta, nakreślona przez liderów, powinna być zrozumiała dla wszystkich jej członków i tak głęboko zakorzeniona w ich świadomości, żeby wiedzieli, co oznacza i jaki kierunek nadaje firmie.
Powyższe rozważania oznaczają zmianę postaw pracowników. W programie Six Sigma pracownicy angażują się w pracę. Nie działają już jak maszyny wykonujące zadania według starych zasad, ale myślą i opracowują nowe rozwiązania prowadzące do usprawnienia produkcji, wyrobów i usług. Wynajdują nowe rozwiązania we wszystkim, czym się zajmują. Są oni źródłem wielu nowych pomysłów i organizacje chętnie korzystają z ich wiedzy.

Łatwo zauważyć, że kultura organizacyjna sprzyjająca takim zachowaniom opierać się będzie na tolerancji, pluralizmie, eksperymentowaniu czy partycypacji pracowników w zarządzaniu. Symbolami wymienionych wartości będą przykładowo: dyskusje z udziałem pracowników z różnych szczebli hierarchii, rozwój organizacyjny i udział pracowników w kierowaniu przedsiębiorstwem. Również usuwanie długotrwałych problemów nie będzie możliwe bez otwartej kultury organizacyjnej.

\section{Podsumowanie}

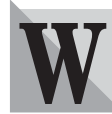
łaściwe funkcjonowanie programu Six Sigma zależy od istnienia odpowiedniej - otwartej - kultury organizacyjnej, której wybrane wartości zaprezentowano powyżej. Problemem staje się więc dostosowanie dotychczasowej kultury organizacyjnej do wyzwań stawianych przez nową metodę. Dokonać tego mają kluczowe osoby związane z programem Six Sigma. Należą do nich tzw. champion oraz osoby określane mianem master black belt $\mathrm{i}$ black belt . To oni odgrywają szczególną rolę w kształtowaniu kultury organizacyjnej, ponieważ wartości, które sami reprezentują, powinny zostać przeniesione na innych uczestników organizacji. Należy jednak pamiętać, że jest to proces złożony i długotrwały, o czym świadczą liczne (nierzadko negatywne) doniesienia z praktyki.

dr inż. Robert Kamiński Instytut Organizacji i Zarządzania Politechniki Wrocławskiej Zakład Systemów Zarządzania i Marketingu

\section{BIBLIOGRAFIA}

[1] BOERNER S., Die Organisation zwischen offener und geschlossener Gesellschaft: Athen oder Sparta?, Duncker und Humblot, Berlin 1994.

[2] HARRY M., SCHROEDER R., Six Sigma. Wykorzystanie programu jakości do poprawy wyników finansowych, Dom Wydawniczy ABC, Kraków 2001.

[3] RUMMLER G.A., BRACHE A.P., Podnoszenie efektywności organizacji, PWE, Warszawa 2000.

[4] ZYMONIK Z., Koszty jakości w zarzadzaniu przedsiębiorstwem, Oficyna Wydawnicza Politechniki Wrocławskiej, Wrocław 2002.

[5] ZYMONIK Z., Koszty jakości w programie Six Sigma, [w:] Nowe tendencje $w$ nauce o organizacji $i$ zarzadzaniu, „Prace Naukowe Instytutu Organizacji i Zarządzania Politechniki Wrocławskiej”, Oficyna Wydawnicza Politechniki Wrocławskiej, Wrocław 2003. 